\title{
TECHNOPRENEURSHIP MAHASISWA PENDIDIKAN TEKNIK MESIN UNIVERSITAS PENDIDIKAN INDONESIA
}

\author{
Rizki A. Nugroho' ${ }^{1}$, Bambang Darmawan², Sulaeman ${ }^{3}$ \\ Universitas Pendidikan Indonesia \\ Jl. Dr. Setiabudhi No. 229 Bandung 40154 \\ rizkiali54@gmail.com
}

\begin{abstract}
ABSRAK
Penelitian ini bertujuan untuk mengetahui kondisi technopreneurship mahasiswa mahasiswa pendidikan teknik mesin, Universitas Pendidikan Indonesia. Metode penelitian menggunakan penelitian deskriptif dengan pendekatan kuantitatif. Populasi dalam penelitian ini adalah mahasiswa pendidikan teknik mesin angkatan 2015 yang berjumlah 129 mahasiswa. Sampel penelitian ditentukan dengan teknik probability sampling dengan cara proportionate stratified random sampling sebanyak 38 mahasiswa. Metode pengumpulan data menggunakan angket. Hasil penelitian menunjukkan bahwa $34 \%$ mahasiswa pendidikan teknik mesin memiliki technopreneurship sangat baik dan $68 \%$ termasuk dalam kategori baik. Rata-rata mahasiswa pendidikan teknik mesin memiliki kemampuan technopreneurship sebesar $78 \%$ yang termasuk baik. Kesimpulan penelitian yaitu bahwa mahasiswa pendidikan teknik mesin telah memiliki kemampuan dalam bidang technopreneurship yang baik.
\end{abstract}

Kata kunci: teknik mesin, kewirausahaan, technopreneurship

\section{PENDAHULUAN}

Pengangguran masih menjadi permasalahan di Indonesia. Penyebab dari pengangguran dan kemiskinan tersebut yaitu perbandingan jumlah lapangan pekerjaan dengan jumlah lulusan atau tenaga kerja yang tidak sebanding atau kurangnya lapangan pekerjaan. Jumlah pengangguran di Indonesia pada Februari 2017 sebanyak 7,01 juta orang dan sebanyak 606.939 orang adalah lulusan perguruan tinggi. Sementara Tingkat Pengangguran Terbuka di perkotaan tercatat cenderung lebih tinggi dibanding di pedesaan. Pada Februari 2017 di perkotaan mencapai 6,5 persen, sedangkan pedesaan hanya 4 persen (Badan Pusat Statistik, 2017). Salah satu penyebab tingginya jumlah pengangguran di kota adalah tingkat urbanisasi yang tinggi. Urbanisasi terjadi karna lapangan pekerjaan banyak terdapat di perkotaan dan menyebabkan jumlah penduduk miskin di desa lebih banyak sehingga berkurangnya sumber daya manusia untuk mengembangkan desa dimana dia berasal. Apabila itu terjadi maka akan meningkatkan kesenjangan antara kehidupan masyarakat di desa dan di kota. Karena desanya tidak ada yang

\footnotetext{
${ }^{1}$ Mahasiswa Departemen Pendidikan Teknik Mesin FPTK UPI

${ }^{2}$ Dosen Departemen Pendidikan Teknik Mesin FPTK UPI

${ }^{3}$ Dosen Departemen Pendidikan Teknik Mesin FPTK UPI
} 
mengembangkan, maka masyarakat desa akan semakin tertinggal dengan masyarakat perkotaan yang selalu berkembang mengikuti perkembangan zaman.

Salah satu peran mahasiswa Departemen Pendidikan Teknik Mesin (DPTM) untuk menjadi solusi dalam mengurangi jumlah pengangguran dan kemiskinan di kota atau di desa adalah menciptakan lapangan pekerjaan baru. Caranya dengan menjadi seorang technopreneur, mendirikan perusahaan terutama di desa. Untuk mengurangi kesenjangan antara kehidupan masyarakat desa dan masyarakat kota pada bidang pendidikan, infrastruktur, teknologi, informasi, dan sebagainya (Direktorat Jenderal Pendidikan Tinggi, 2008). Departemen Pendidikan Teknik Mesin yang menekankan pada disiplin ilmu pendidikan teknik mesin yang diharapkan dapat menghasilkan sumber daya manusia (SDM) yang dibutuhkan oleh Indonesia. Mahasiswa telah dibekali pengetahuan pada bidang teknologi yang diharapkan dapat menciptakan lapangan pekerjaan dengan melakukan penciptaan barang atau jasa berbasis teknologi melalui penelitian dan disesuaikan dengan kebutuhan masyarakat. Proses pembentukan dan kolaborasi antara bidang usaha dan penerapan teknologi sebagai instrumen pendukung dan sebagai dasar dari usaha itu sendiri, baik dalam proses maupun produk yang dihasilkan disebut tecnopreneurship. Hal yang harus diperhatikan dalam technopreneurship ini adalah penelitian dan komersialisasi (Baihaqi dan Nurif, 2015).

Apabila ditinjau dari daerah asal adalah lingkungan yang heterogen karena setiap mahasiswa berasal dari daerah yang berbeda-beda yang tersebar di seluruh penjuru tanah air. Dengan diberikannya mata kuliah kewirausahaan diharapkan mahasiswa memiliki ilmu tentang kewirausahaan. Mereka diharapkan bisa membangun sebuah usaha guna menciptakan lapangan pekerjaan untuk diri sendiri dan orang lain. Didorong untuk mengembangkan daerah dimana mahasiswa berasal dengan menjadi seorang technopreneur. Sejalan dengan tujuan pendidikan tinggi, yaitu: kritis, kreatif, inovatif, mandiri, percaya diri dan berjiwa wirausaha (Astamoen, 2008).

\section{METODE PENELITIAN}

Penelitian ini menggunakan metode penelitian deskriptif dengan pendekatan kuantitatif. Penelitian deskriptif kuantitatif merupakan Penelitian deskriptif dalam penelitian ini, dimaksudkan untuk mengetahui technopreneurship mahasiswa DPTM FPTK UPI. Populasi penelitian pada penelitian ini adalah mahasiswa DPTM FPTK UPI semester 6. Sampel pada 
penelitian ini menggunakan sampling purpose. Instrumen yang digunakan yaitu kuesioner yang kemudian diberikan kepada sampel terpilih. Validitas instrumen yang digunakan adalah validitas konstruksi. Validitas konstruks diperoleh dengan cara uji validitas atau meminta pertimbangan kepada para ahli (expert judgement). Pengujian validitas dimaksudkan untuk mendapatkan tingkat kevalidan dan kesahihan suatu instrument. Data yang telah diperoleh tersebut diolah dengan menggunakan rumus perhitungan rata-rata persentase.

\section{HASIL PENELITIAN}

Technopreneur memiliki gambaran pribadi atau profil yang bisa diterapkan pada usahanya yang bertujuan untuk mengembangkan bisnisnya. Terdapat beberapa indikator yang diambil dalam penelitian ini antara lain: optimalisasi teknologi dan informasi, implementasi keilmuan teknis rekayasa, percaya diri, berorientasi tugas dan hasil, pengambil resiko, kepemimpinan, orisinalitas, dan berorientasi masa depan. Indikator ini menjadi acuan untuk melihat profil technopreneurship mahasiswa (Nurfaizal, 2014). Hasil penelitian menunjukkan bahwa technopreneurship mahasiswa dilihat dari profil technopreneurship pada setiap indikator berbeda-beda. Indikator optimalisasi teknologi dan informasi sebesar $81 \%$ (baik), implementasi keilmuan teknis rekayasa sebesar 79\% (baik), percaya diri sebesar 80\% (baik), berorientasi tugas dan hasil sebesar $77 \%$ (baik), pengambil resiko sebesar sebesar 78\% (baik), kepemimpinan sebesar $81 \%$ (baik), orisinalitas sebesar 79\% (baik), dan berorientasi masa depan $79 \%$ (baik). Mahasiswa memiliki kemampuan optimalisasi teknologi dan informasi serta kepemimpinan yang tergolong dalam kategori sangat baik, sedangkan pada enam indikator lainnya tergolong pada kategori baik.

Sifat seseorang akan mempengaruhi sikapnya dalam berperilaku. Perilaku yang relatif diulang-ulang akan membentuk sebuah karakter. Terdapat beberapa indikator karakteristik technopreneurship, antara lain: lebih menyukai pekerjaan dengan resiko yang realistik, bekerja lebih giat pada tugas-tugas yang memerlukan kemampuan mental, tidak menjadi bekerja lebih giat dengan adanya imbalan uang, ingin bekerja pada situasi yang dapat diperoleh pencapaian pribadi (personal achievement), menunjukkan kinerja yang lebih baik dalam kondisi yang memberikan umpan-balik yang jelas dan positi, cenderung untuk berpikir ke masa depan dan memiliki pemikiran untuk jangka panjang. Indikator ini menjadi acuan untuk melihat karakteristik technopreneurship mahasiswa (Sudarsih, 2013). Hasil penelitian ini menunjukkan 
technopreneurship mahasiswa dilihat dari berbagai indikator karakteristik technopreneurship. Indikator Lebih menyukai pekerjaan dengan resiko yang realistik sebesar $72 \%$ (baik), bekerja lebih giat pada tugas-tugas yang memerlukan kemampuan mental 74\% (baik), tidak menjadi bekerja lebih giat dengan adanya imbalan uang 63\% (baik), ingin bekerja pada situasi yang dapat diperoleh pencapaian pribadi (personal achievement) 68\% (baik), menunjukkan kinerja yang lebih baik dalam kondisi yang memberikan umpan-balik yang jelas dan positif 74\% (baik), cenderung untuk berpikir ke masa depan dan memiliki pemikiran untuk jangka panjang $82 \%$ (sangat baik). Mahasiswa cenderung untuk berpikir ke masa depan dan memiliki pemikiran untuk jangka panjang yang tergolong dalam kategori sangat baik. Pada lima indikator lainnya tergolong dalam kategori baik. Technopreneurship yang dimaksud pada penelitian ini dilihat dari 2 aspek, yaitu: profil technopreneurship dan karakteristik technopreneurship.

Hasil penelitian menunjukkan bahwa technopreneurship mahasiswa dari aspek profil technopreneurship 79\% (baik) dan karakteristik technopreneurship 72\% (baik). Kedua aspek yang dimaksud termasuk dalam kategori baik. Nilai persentase technopreneurship mahasiswa DPTM FPTK UPI sebesar 78\% termasuk pada kategori baik.

\section{PEMBAHASAN}

Technopreneur secara sederhana dapat diartikan sebagai seorang peminat teknologi yang memiliki jiwa entrepreneur. Tanpa jiwa entrepreneur seorang peminat teknologi hanya menjadi teknsi dan kurang dapat menjadikan teknologi yang digelutinya sebagai sumber kehidupannya. Hasil penelitian pada indikator ini menunjukkan persentase $81 \%$. Artinya mahasiswa sudah mengikuti perkembangan teknologi dan informasi. Technopreneurship pemanfaatan teknologi berpengaruh pada pengembangan usaha sekaligus untuk mengoptimalkan proses hasil dari usaha yang dikembangkan tersebut (Jain, 2014). Kolaborasi antara penerapan teknologi sebagai instrumen dan usaha mandiri sebagi kebutuhan. Hal ini menunjukkan bahwa kriteria dalam indikator ini tergolong pada kategori baik. Secara garis besar, mahasiswa sudah baik dalam mengoptimalkan perkembangan teknologi dan informasi.

Technopreneurship yaitu mengaplikasikan bisnisnya dengan kemampuan ilmu pengetahuan dan teknologi. Berbagai kemajuan yang dicapai diawali dengan riset dan temuantemuan baru dalam bidang teknologi yang kemudian dikembangkan sedemikan rupa. Perkembangan bisnis dalam bidang teknologi bermula dari ide kreatif yang mampu 
dikembangkan, sehingga memiliki nilai jual di pasar. Karya yang nyata harus dapat dimanfaatkan secara langsung dalam usaha. Proses rekayasa teknologi menjadi tujuan akhir dari pengaplikasian sains dan ilmu-ilmu yang dipelajari. Hasil penelitian pada indikator ini menunjukkan persentase 79\%. Artinya mahasiswa sudah menerapkan keilmuan teknis rekayasa dengan baik.

Sikap penuh keyakinan, kemandirian, individualitas dan optimis merupakan watak seseorang yang memliki kepercayaan diri dalam dirinya. Termasuk dalam melakukan sesuatu, tanpa kepercayaan diri seseorang akan mudah terpengaruh dan kurang yakin melakukan sebuah tindakan. Tingkat percaya diri yang tinggi terutama percaya diri akan keberhasilan usahanya seseorang akan tetap fokus dan akan berusaha lagi dan tidak mudah menyerah. Hasil penelitian pada indikator ini menunjukkan persentase $80 \%$. Artinya mahasiswa sudah memiliki kepercayaan diri yang baik untuk mendirikan suatu usaha. Selalu ingin berprestasi, berorientasi hasil, tekun, tabah, tekat, kerja keras, memiliki dorongan yang kuat, enerjik, dan berinisiatif merupakan watak dari seseorang yang memiliki pikiran yang berorientasi pada tugas dan hasil. Hasil penelitian pada indikator ini menunjukkan persentase 77\%. Artinya mahasiswa dalam melakukan tindakan akan berorientasi pada tugas dan hasil yang mereka ingin capai.

Pengusaha memiliki keberanian untuk mempertahankan waktu, tenaga, reputasi bisnis, dan dana yang diinvestasi untuk kegiatan usaha. Seorang pengusaha juga harus memiliki kemampuan mengambil resiko dan menyukai tantangan atau tidak banyak mengeluh ketika berada dalam kesulitan. Hasil penelitian pada indikator ini menunjukkan persentase $78 \%$. Artinya mahasiswa/responden adalah seorang pengambil resiko yang baik. Seseorang dituntut untuk tidak bergantung kepada orang lain. Termasuk dalam mengatur hidupnya yang berarti seseorang harus bisa menjadi seorang pemimpin, baik untuk dirinya sendiri atau untuk memimpin orang lain. Hasil penelitian pada indikator ini menunjukkan persentase $81 \%$. Artinya mahasiswa dapat menjadi seorang pemimpin yang baik.

Seseorang diciptakan dengan ciri yang berbeda-beda, tidak sama antara satu dengan yang lainnya. Dalam melakukan sebuah usaha orisinalitas sangat diperlukan untuk mengembangkan usahanya supaya tidak melakukan plagiat karya orang lain. beberapa watak orang yang memiliki orisinalitas antara lai: fleksibel, memiliki banyak sumber, serba bisa, mengetahui banyak hal. Hasil penelitian pada indikator ini menunjukkan persentase $79 \%$. Artinya mahasiswa/responden memiliki tingkat orisinalitas yang baik. 
Sebuah perencanaan sangat penting dalam mendirikan sebuah usaha. merencanakan sesuatu tidak cukup untuk jangka waktu yang pendek saja, perlu melakukan perencanaan jangka panjang pula. maka dari itu seseorang harus selalu berorientasi pada masa depan untuk dapat melakukan pernecanaan dalam jangka panjang. Hasil penelitian pada indikator ini menunjukkan persentase $79 \%$. Artinya mahasiswa memiliki orientasi masa depan yang baik.

Setiap pekerjaan memiliki resiko dan seseorang harus sepandai mungkin dalam melakukan pengambilan resiko yang tepat. Dalam hal ini seorang technopreneur lebih menyukai pekerjaan dengan resiko yang realistik yang menurut mereka sesuai dengan kemampuan yang mereka miliki. Hasil penelitian pada indikator ini menunjukkan persentase $72 \%$. Artinya mahasiswa memiliki kemampuan yang baik dalam pemilihan pekerjaan dengan resiko yang realsitik. Seorang technopreneur akan semakin termotivasi untuk menyelesaikan tugas-tugas kompleks. Mereka akan lebih giat/semangat dalam mengerjakan tugas-tugas yang memerlukan kemampuan mental yang kuat (Suyatno dan Muhtarom, 2018). Hasil penelitian pada indikator ini menunjukkan persentase $74 \%$. Artinya mahasiswa akan lebih giat ketika diberikan tugas-tugas yang memerlukan kemampuan mental dan dapat melakukannya dengan baik. Pengusaha merupakan manajer yang kegiatannya tidak hanya berfikir untung-rugi bagi dirinya tetapi juga berusaha untuk memikirkan pengabdian dan mewujudkan tekatnya kepada masyarakat dan negara. Seorang technopreneur bekerja bukan hanya karena imbalan uang (Nasution, et. al., 2007). Hasil penelitian pada indikator ini menunjukkan persentase $63 \%$. Artinya mahasiswa dapat melakukan pekerjaan dengan baik bukan karena imbalan uang.

Seorang pengusaha kegiatannya yaitu untuk menumbuhkan kepercayaan masyarakat atas kemampuan dirinya, memenuhi kebutuhan masyarakat sehingga semakin membaik, memperluas kesempatan kerja bagi rakyat banyak, berupaya mengakhiri ketergantungannya kepada pihak luar dan orang lain. Sehingga dapat dismpulkan bahwa mereka menginginkan pencapaiam pribadi bagi diri mereka. Hasil penelitian pada indikator ini menunjukkan persentase $68 \%$. Artinya mahasiswa memiliki keinginan yang baik untuk bekerja pada situasi yang diperoleh pencapaian pribadi.

Setiap perlakuan akan mendapatkpan umpan balik, terkadang umpan balik yang didapatkan positif dan terkadang juga negatif. Untuk memberikan umpan balik, dapat bersifat verbal atau nonverbal. Evaluatif yaitu menggunakan umpan balik untuk menentukan tindakan yang lebih efektif guna mencapai prestasi, kegagalan yang dialami tidak membuatnya putus asa, 
melainkan sebagai pelajaran untuk berhasil. Seorang technopreneur akan menunujukkank inerja yang lebih baik dalam kondisi yang memberikan umpan balik yang jelas dan positif (Direktorat Jenderal Pendidikan Tinggi, 2008). Hasil penelitian pada indikator ini menunjukkan persentase 74\%. Artinya mahasiswa/responden ketika mendapatkan umpan balik yang jelas dan positif mereka akan menunjukkan kinerja yang lebih baik. Sebuah perencanaan sangat penting dalam mendirikan sebuah usaha. merencanakan sesuatu tidak cukup untuk jangka waktu yang pendek saja, perlu melakukan perencanaan jangka panjang pula. maka dari itu seseorang harus selalu berorientasi pada masa depan untuk dapat melakukan pernecanaan dalam jangka panjang. Hasil penelitian pada indikator ini menunjukkan persentase $82 \%$. Artinya mahasiswa memiliki pemikiran untuk jangka panjang yang sangat baik.

\section{KESIMPULAN}

Kesimpulan penelitian menuunjukkan bahwa mahasiswa DPTM S-1 FPTK UPI memliki potensi untuk yang baik untuk dapat menjadi seorang technopreneur. Mahasiswa tersebut telah memliki profil dan karakteristik technopreneurship yang baik dalam dirinya. Mahasiswa DPTM FPTK UPI sudah memiliki potensi untuk menjadi seseorang yang bermanfaat atau dampak baik secara ekonomi, sosial, maupun lingkungan masyarakat.

\section{REFERENSI}

Astamoen, M.P. (2008). Entrepreneurship. Bandung: Alfabeta

Badan Pusat Statistik. (2017). Jumlah Pengangguran di Indonesia. Jakarta: BPS

Baihaqi dan Nurif. (2015). Technopreneurship. Surabaya: LP2KHA ITS

Direktorat Jenderal Pendidikan Tinggi. (2008). Technopreneurship. Jakarta: Depdiknas.

Jain, V. (2014). 3D Model of Attitude. International Journal of Advanced Research in Management and Social Scienses, 4(2).

Nasution, A. H., Arifin, E., dan Suef, M. (2007). Entrepreneurship: Membangun Spirit Technopreneurship. Yogyakarta: Andy Offset

Nurfaizal, Y. (2014). Perilaku Technopreneur Mahasiswa Teknik Informatika: Tinjauan Pada Self-Sufficiency. Jurnal Fokus Bisnis, 14, 13-25. 
Sudarsih, E. (2013). Pendidikan Technopreneurship: Meningkatkan Daya Inovasi Mahasiswa Teknik dalam Berbisnis. Konferensi Nasional Inovasi dan Technopreneurship. Bogor: IPBICC

Suyatno, A. dan Muhtarom, M. (2018). Pengaruh Lingkungan Keluarga dan Pembelajaraan Kewirausahaan terhadap Intensi Technopreneurship Mahasiswa Manajemen Ilmu Komputer. Prosiding SENDI_U. ISBN: 978-979-3649-99-3. 